\title{
Irfani
}

ISSN 1907-0969 E ISSN 2442-8272

Volume 14 Nomor 1 Juni 2019

Halaman 25-35

http://journal.iaingorontalo.ac.id/index.php/ir

\section{HUBUNGAN KONSEP DIRI AKADEMIK DENGAN BELAJAR BERDASAR REGULASI DIRI PADA SISWA KELAS XII MAN KOTAMOBAGU}

\author{
Kusmawaty Matara \\ IAIN Sultan Amai Gorontalo \\ email: kusmawaty.matara83@gmail.com
}

\begin{abstract}
ABSTRAK
Penelitian ini bertujuan untuk menguji secara empiris dan mengetahui gambaran hubungan antara konsep diri akademik dengan belajar berdasar regulasi diri pada siswa kelas XII MAN Kotamobagu Sulawesi Utara. Subyek dalam penelitian ini adalah 80 siswa Kelas XII MAN Kotambagu. Pengumpulan data dilakukan dengan menggunakan 2 skala yaitu konsep diri akademik dan belajar berdasar regulasi diri. Analisis data diolah dengan metode analisis regresi menggunakan program SPS-versi 15.0 for window. Hasil penelitian menunjukkan terdapat hubungan yang sangat signifikan konsep diri akademik dengan belajar berdasar regulasi diri pada siswa kelas XII MAN Kotamobagu. Hal ini ditunjukkan dengan perolehan nilai $F=11,614$ dengan $p$ $=0,00(p<0.01)$. Konsep diri akademik berperan sebesar 16,6\% dan 83,4\% dijelaskan oleh faktor-faktor lain yang tidak dilibatkan dalam penelitian. Hasil uji analisis konsep diri akademik dengan belajar berdasar regulasi diri pada siswa kelas XII MAN Kotamobagu, terdapat hubungan positif yang sangat signifikan. Nilai yang diperoleh dari korelasi parsial sebesar $=0,402$ t hitung $=0,4737$ dengan $p=0.00(p<0.01)$.
\end{abstract}

Kata kunci : konsep diri akademik dan belajar berdasar regulasi diri.

\section{PENDAHULUAN}

Manusia pada dasarnya adalah makhluk yang mempunyai potensi yang telah dianugrahkan Tuhan kepadanya sejak lahir. Salah satu cara untuk mengembangkan potensi yang telah dimiliki manusia adalah melalui pendidikan. Pendidikan merupakan poses kehidupan yang dapat mengembangkan manusia kearah yang lebih baik. Melalui pendidikan manusia diharapkan mampu untuk menghasilkan individu yang berkualitas, dengan pribadi yang tangguh dengan kekuatan spiritual keagamaan, moral, akhlak mulia, kecerdasan serta keterampilan yang diperlukan untuk kehidupan dirinya dan masyarakat.

Pendidikan memegang peranan penting dalam pembangunan dan merupakan kunci utama untuk mencapai kemajuan suatu bangsa. Salah satu tujuan pembangunan di Indonesia adalah untuk mencerdaskan kehidupan bangsa seperti yang tercantum dalam UUD 1945 dan tujuan tersebut dapat dicapai melalui pendidikan. Untuk itu pemerintah memberikan perhatian yang cukup besar terhadap sektor pendidikan. Pendidikan merupakan wahana untuk meningkatkan dan mengembangkan kualitas sumber daya manusia (SDM).

Melihat begitu pentingnya masalah pendidikan, pemerintah sebagai pemegang kebijakan menetapkan dalam undang-undang pendidikan, dengan membagi pendidikan 


\section{Irfani}

ISSN 1907-0969 E ISSN 2442-8272

Volume 14 Nomor 1 Juni 2019

Halaman 25-35

http://journal.iaingorontalo.ac.id/index.php/ir

menjadi pendidikan formal, non formal dan informal, yang semuanya bertujuan untuk mengembangkan potensi-potensi yang ada dalam diri setiap manusia, demi mencapai kualitas sumber daya manusia yang baik.

Pendidikan yang menentukan seorang siswa dinyatakan telah mengenyam bangku sekolah apabila telah mengikuti pendidikan formal. Pendidikan formal merupakan pendidikan yang terencana, terstruktur, berjenjang mulai pendidikan dasar sampai perguruan tinggi dengan tujuan dan bahan ajar terstruktur, yang dalam penyelenggaraannya setiap sekolah harus mengikuti peraturan-peraturan yang telah ditetapkan pemerintah.

Salah satu upaya pemerintah untuk memperbaiki mutu pendidikan adalah dengan diselenggarakannya Ujian Nasional. Pemerintah menyelenggarakan ujian nasional memiliki tujuan-tujuan tertentu seperti tertuang dalam Peraturan Menteri Pendidikan Nasional (PERMEN ) No. 77 Tahun 2008 tentang UN seluruh SMA/Madrasyah Aliyah, bahwa ujian nasional bertujuan menilai pencapaian kompetensi lulusan secara nasional pada mata pelajaran tertentu dalam kelompok mata pelajaran ilmu pengetahuan dan teknologi. Hasil UN digunakan sebagai salah satu pertimbangan untuk; a. pemetaan mutu satuan dan/atau program pendidikan ; b. dasar seleksi masuk jenjang pendidikan berikutnya; c. penentuan kelulusan peserta didik dari program dan/atau satuan pendidikan; d.pembinaan dan pemberian bantuan kepada satuan pendidikan dalam upaya peningkatan mutu pendidikan. Upaya lain adalah adanya sertifikasi profesi guru, penyelenggaraan kelas akselerasi dan kelas berstandar Internasional (SBI).

Tetapi yang tidak kalah pentingnya adalah pengembangan pribadi siswa itu sendiri dalam menjalankan proses pembelajaran. Pada saat sekarang ini semakin tingginya tuntutan pendidikan sejalan dengan daya saing yang semakin tinggi dalam segala bidang kehidupan, maka siswa dituntut untuk semakin giat dan aktif dalam belajar, siswa tidak bisa hanya pasif menerima pembelajaran di kelas. Siswa betul-betul harus aktif melibatkan diri dalam belajar, mau mencari, mengolah berbagai informasi, memanfaatkan sumber daya yang ada di lingkungan untuk mencapai proses pembelajaran yang optimal.Salah satu proses pembelajaran untuk mencapai hasil belajar yang optimal dan meningkatkan prestasi belajar siswa adalah belajar berdasar regulasi diri.

Pentingnya siswa belajar dengan aktif, terarah, dan strategis dalam hal ini mampu belajar berdasar regulasi diri mendorong para peneliti untuk melakukan penelitian yang berkaitan dengan pentingya belajar berdasar regulasi diri dalam proses pembelajaran. Salah satunya Pintrich dan De Groot (1990) meneliti tentang motivasi dan tampilan akademik. Hasil penelitinnya adalah nilai intrinsik tidak berpengaruh langsung pada performasi tetapi berhubungan sangat kuat dengan regulasi diri dan strategi kognisi yang dipergunakan, berhubungan dengan tingkat prestasi yang diraih. Hasil penelitian tersebut menggambarkan belajar regulasi diri akan mampu untuk mencapai prestasi akademik. Hal ini berarti belajar berdasar regulasi diri memang perlu diterapkan dan dikembangkan kepada para siswa agar dapat mencapai proses pembelajaran yang baik.

Hasil beberapa penelitian yang disimpulkan oleh Chen (2000) bahwa kemampuan personal yang membuat siswa mampu belajar secara independen dalam hal ini belajar berdasar regulasi diri, berhubungan dengan tingginya tingkat prestasi yang diraih. Selain 


\section{Irfani}

ISSN 1907-0969 E ISSN 2442-8272

Volume 14 Nomor 1 Juni 2019

Halaman 25-35

http://journal.iaingorontalo.ac.id/index.php/ir

itu regulasi diri dalam kognisi dan perilaku merupakan aspek penting dalam pembelajaran siswa dan performasi siswa di kelas (Corno \& Mardinach ; Corno \& Rohrkemper, dalam Pitrich \& De Groot, 1999).

Belajar berdasar regulasi diri diartikan dari self regulated learning dari Zimmerman (1989). Dalam penelitian ini self regulated leraning diartikan sebagai belajar berdasar regulasi diri pengertian ini berdasarkan penelitian Alsa (2005) Menurut Zimmerman (1989) pengertian belajar berdasar regulasi diri adalah mengatur atau mengarahkan diri dalam belajar atau belajar dengan mengarahkan atau mengatur diri. Lebih lanjut Zimmerman (1989) menjelaskan belajar berdasar regulasi diri suatu upaya yang mengacu pada kemampuan individu untuk mengatur dirinya dalam proses belajar, dengan mengikutsertakan kemampuan metakognisi, motivasi dan perilaku aktif.

Belajar berdasar regulasi diri ini harus dimiliki oleh semua siswa seperti yang diungkapkan oleh Peverly dkk (dalam Alsa, 2005) bahwa individu yang melakukan belajar berdasar regulasi diri sebagai individu yang memiliki pengetahuan dan tujuan strategis serta kemandirian untuk mengerahkan kemampuannya secara efektif dalam belajar. Dengan kemampuan melakukan belajar berdasar regulasi diri maka siswa diharapkan mampu untuk meningkatkan efektivitas belajarnya sehingga prestasi belajar siswa juga akan meningkat.

Berdasarkan hasil penelitian di atas maka penulis berkesimpulan bahwa belajar berdasar regulasi diri merupakan salah satu kemampuan penting dalam proses belajar yang harus dilakukan siswa karena dapat meningkatkan efektivitas belajar yang mengarah pada peningkatan prestasi belajar yang optimal. Belajar berdasar regulasi diri tersebut dapat dimiliki dan dilakukan oleh setiap siswa dengan didukung oleh kondisi yang dapat mengarahkan untuk terciptanya belajar berdasar regulasi diri. Belajar berdasar regulasi diri perlu dikembangkan di dalam proses belajar karena belajar berdasar regulasi diri penting untuk sistem pendidikan secara keseluruhan. Dengan demikian peneliti tertarik untuk melakukan penelitian yang berkaitan dengan belajar berdasar regulasi diri. Hal ini dengan pemikiran bahwa apabila siswa telah mampu untuk melakukan belajar berdasar regulasi diri maka, akan mengarahkan siswa mencapai performasi akademik yang baik.

Selanjutnya untuk memperoleh gambaran kondisi siswa dalam proses pembelajaran, peneliti melakukan survei pada tanggal 3 dan 4 April 2018 terhadap salah satu sekolah Kelas XII MAN Kotamobagu. Hal ini dilakukan untuk mengetahui antara siswa dan sekolah dalam proses belajar mengajar khususnya pada siswa kelas XII yang akan menghadapi ujian. Survei berkaitan dengan upaya-upaya yang telah dilakukan siswa maupun sekolah dalam proses pembelajaran salah satunya dalam menghadapi ujian nasional. Survei tersebut dilakukan di sekolah Kelas XII MAN Kotamobagu. Sekolah ini termasuk salah satu sekolah negeri yang banyak peminatnya bagi mereka yang tidak diterima sekolah lainya, sekolah MAN Kotamobagu juga memiliki siswa yang sangat hoterogen terutama latar belakang keluarganya yaitu tingkat sosial ekonominya mulai dari tingkat bawah sampai dengan status sosial ekonomi yang tinggi.

Pihak sekolah selama ini telah melakukan berbagai upaya dalam meningkatkan proses pembelajaran agar siswa dapat mencapai keberhasilan dalam belajar, salah satu keberhasilan siswa yaitu siswa dapat berhasil lulus dalam menghadapi UN dengan hasil 


\section{Irfani}

ISSN 1907-0969 E ISSN 2442-8272

Volume 14 Nomor 1 Juni 2019

Halaman 25-35

http://journal.iaingorontalo.ac.id/index.php/ir

yang baik. Untuk mencapai keberhasilan proses belajar tersebut sekolah mencoba untuk menyediakan fasilitas di antaranya dengan adanya perpustakaan, para guru khususnya guru mata pelajaran UN membuat modul-modul, dan untuk menghadapi UN pihak sekolah telah melakukan kegiatan belajar yang dirancang khusus. Hasil wawancara peneliti dengan pihak sekolah yaitu Wakil Kepala Sekolah Bidang Kurikulum mengatakan bahwa dalam rangka menghadapi UN maka untuk kelas XII pihak sekolah mengadakan pemantapan mulai dari semester kesatu yaitu memperpanjang jam pelajaran mata pelajaran UN. Pada semester kedua waktu pelaksanaan ujian sudah dekat maka sekolah menyelenggarakan pemantapan khusus di luar jam pelajaran. Pemantapan dilaksanakan selama 2 jam dengan tryout 3 kali, pelaksanaan tryout dilakukan oleh pihak sekolah sendiri maupun bekerjasama dengan lembaga bimbingan belajar. Para guru yang mengajar mata pelajaran yang termasuk UN membuatkan modul untuk semua mata pelajaran UN. Namun pada kenyataannya masih banyak siswa yang kurang sungguhsungguh mempersiapkan diri untuk menghadapi UN tersebut. Sebetulnya siswa merasa stres akan menghadapi UN karena hasil UN akan menentukan kelulusan mereka, tetapi perilaku siswa dalam belajar justru kurang giat. Hasil wawancara dan observasi peneliti seperti mereka banyak yang hanya belajar apabila ada PR, bahkan banyak siswa yang baru mengerjakan PR di sekolah dan dalam mengerjakannya hanya menyalin dari temannya, siswa juga kurang rajin dalam mengerjakan latihan-latihan soal yang telah diberikan, mereka hanya melakukan latihan selama di sekolah.

Untuk memperoleh gambaran yang lebih jelas tentang kondisi siswa tersebut maka peneliti juga melakukan survei awal terhadap 30 siswa kelas XII IPA dengan melakukan pengukuran belajar berdasar regulasi diri. Peneliti mengajukan 21 pertanyaan yang diambil beberapa pertanyaaan dari alat ukur MSQL sebagai sampel untuk memperoleh gambaran tentang belajar berdasar regulasi diri yang meliputi komponen motivasi (4 pertanyaan), komponen kognitif (7 pertanyaan) dan komponen behavioral (10 pertanyaan). Berdasarkan hasil survei tersebut maka peneliti menemukan adanya indikasi bahwa umumnya siswa dalam belajar belum terdorong untuk belajar sungguh sungguh, belum ada perencanaan atau memanfaatkan sumber daya artinya siswa belum menggambarkan bahwa mereka telah melakukan belajar berdasar regulasi diri dalam mengolah hasil pembelajarannya. Dalam hal ini tergambar dari data survei bahwa untuk aspek-aspek motivasional hanya $29 \%$ yang menunjukkan bahwa siswa memiliki efikasi diri yang tinggi, atribusí diri, minat intrinsik terhadap belajar serta usaha dalam menghadapi tantangan jadi lebih banyak siswa yang aspek motivasionalnya rendah, dan hanya $31 \%$ siswa aktif merencanakan, mengorganisasikan, mengatur diri, memantau diri dan mengevaluasi diri pada berbagai tahap dalam proses belajar, sedangkan behavioral siswa hanya $21 \%$ aktif memilih, menstruktur dan menciptakan lingkungan yang dapat mengoptimalkan belajar, mencari saran, mencari informasi dan memanfaatkan lingkungan untuk menciptakan belajar dengan belajar berdasar regulasi diri. Berdasarkan hasil pra- penelitian siswa belum sepenuhnya melakukan belajar berdasar rgulasi diri, bahkan hasilnya menunjukkan jauh di bawah 100\%. Masih rendahnya belajar berdasar regulasi siswa dapat berdampak pada pencapaian hasil pembelajaran yang optimal. 


\section{Irfani}

ISSN 1907-0969 E ISSN 2442-8272

Volume 14 Nomor 1 Juni 2019

Halaman 25-35

http://journal.iaingorontalo.ac.id/index.php/ir

Menurut Zimmerman (1989) faktor yang mempengaruhi belajar berdasar regulasi diri antara lain faktor individu (person), perilaku (behavior) dan lingkungan. Berdasarkan hal tersebut dalam penelitian ini peneliti akan melihat keterkaitan faktor tersebut. Dalam hal ini faktor individu sebagi faktor internal dan faktor lingkungan sebagai faktor ekternal. Menurut para ahli untuk mencapai keberhasilan dalam proses belajar terkait dengan beberapa faktor yaitu faktor personal, sosial, keluarga, pengajaran dan lingkungan. Peneliti kelompokan menjadi faktor internal dan eksternal.

Demikian pula dengan belajar berdasar regulasi diri yang merupakan salah satu upaya dalam mencapai keberhasilan dalam proses pembelajaran diperlukan faktor internal maupun eksternal agar siswa mampu melakukan belajar berdasar regulasi diri. Butler (dalam Susetyo, 2007) menyatakan bahwa penelitian tentang belajar berdasar regulasi diri menunjukkan pentingnya kontek sosial. Perkembangan ini menunjukkan bahwa belajar berdasar regulasi diri bukan pengetahuan dan keterampilan individu yang steril dari pengaruh konteks sosial, namun justru melibatkan konteks sosial termasuk teman sebaya dan guru. Menurut para ahli bahwa untuk mencapai keberhasilan dalam proses belajar terkait dengan beberapa faktor yaitu faktor personal, sosial, keluarga, pengajaran dan lingkungan (Berliner \& Biddle, 1997; Steinberg, Brown \& Dornbusch, 1996; Thompson, Detterman, \& Plomin, 1991).

Berkaitan dengan faktor yang mempengaruhi belajar berdasar regulasi diri adalah faktor individu sebagai faktor internal salah satunya adalah konsep diri akademik Konsep diri akademik merupakan salah satu komponen dari motivasi yang akan menggerakan siswa dalam belajar berdasar regulasi diri. Konsep diri akademik gambaran siswa dalam memandang dirinya sendiri menyangkut kemampuan akademiknya (Shevelson dalam Marsh \& Yeung, 1997). Seperti yang diungkapkan oleh Chapman dkk. (2000) bahwa konsep diri akademik merupakan dasar dari prestasi akademik dan perilaku akademik. Oleh karena itu konsep diri akademik mempunyai peranan penting dalam perkembangan individu, terutama dalam kelangsungan pendidikan dengan konsep diri akademik yang positif dapat mendorong siswa untuk melaksanakan tugasnya sebagai siswa terutama dalam mengolah hasil pembelajarnnya.

Sehubungan uraian diatas, peneliti bermaksud menguji secara empiris konsep diri akademik dengan belajar berdasar regulasi diri pada siswa kelas XII MAN Kotamobagu Provinsi Sulawesi Utara, dengan tujuan penelitian ini untuk menguji secara empiris dan mengetahui gambaran hubungan antara konsep diri akademik dengan belajar berdasar regulasi diri pada siswa kelas XII MAN Kotamobagu.

\section{METODE PENELITIAN}

Data yang diperoleh dalam penelitian ini akan dianalisis dengan menggunakan teknik statistik. Penelitian ini terdiri atas satu variabel bebas dan satu variabel tergantung. Teknik analisa statistik yang digunakan dalam penelitian ini adalah analisis regresi.

Penelitian ini menggunakan teknik pelaporan diri (self report) skala psikologis, berupa angket. Dalam penelitin ini variabel yang akan diukur terdiri dari variable ; 1) variabel konsep diri akademik; 2) variabel belajar berdasar regulasi diri. variabel konsep diri akademik terdiri dari aspek kepercayaan diri, penerimaaan dan penghayatan diri, 


\section{Irfani}

ISSN 1907-0969 E ISSN 2442-8272

Volume 14 Nomor 1 Juni 2019

Halaman 25-35

http://journal.iaingorontalo.ac.id/index.php/ir

sedangkan belajar berdasar regulasi diri direncanakan diukur dengan skala MSLQ yang telah dikembangkan oleh Alsa (2005), dengan alasan karakteristik sample hampir sama.

1. Skala Konsep Diri Akademik

Penyusunan skala konsep diri akademik disusun sendiri oleh penulis berdasarkan teori yang dikemukakan oleh (Marsh dalam Munajat, 2005). Skala konsep diri akademik ini menggunakan skala model Likert. Penilaian dalam skala ini meminta responden untuk menyatakan taraf kesesuaian terhadap isi pernyataan. Bentuk jawaban terbagi empat sangat sesuai, sesuai, tidak sesuai dan sangat tidak sesuai. Penyusunan skala konsep diri akademik disusun sendiri oleh penulis berdasarkan teori yang dikemukakan oleh (Marsh dalam Munajat, 2005). Skala konsep diri akademik ini menggunakan skala model Likert. Penilaian dalam skala ini meminta responden untuk menyatakan taraf kesesuaian terhadap isi pernyataan. Bentuk jawaban terbagi empat sangat sesuai, sesuai, tidak sesuai dan sangat tidak sesuai, dengan aspek yang dinilai; kepercayaan diri, penerimaan diri, penghargaan diri.

2. Skala belajar berdasar regulasi diri.

Pengukuran belajar berdasar regulasi diri dengan menggunakan Motivated Strategies for Learning Quisioner (MSLQ). MSLQ mengukur motivasi dan strategi belajar yang dipakai oleh pelajar. Instrumen ini menggunakan skala Likert dengan tujuh alternatif jawaban, mulai dari jawaban "sangat tidak setuju" (skor 1) sampai jawaban "sangat benar" (skor 7), dengan aspek yang dinilai; regulasi metakognitif, strategi kognitif, strategi pengelolaan lingkungan sumber daya.

Populasi dalam lokus penelitian ini sebanyak 130, besarnya sampel adalah 80 orang. Pertimbangan peneliti menentukan jumlah sampel berdasarkan waktu dan biaya, dengan pertimbangan bahwa karakteristik sampel homogen. Penentuan sample dilakukan dengan cara non random yaitu subyek yang dapat dijadikan sample penelitian ditentukan oleh pemegang kebijakan dengan pertimbangan kelas yang pada saat akan dilakukan pengambilan data tidak ada kegiatan belajar mengajar.

\section{HASIL PENELITIAN DAN PEMBAHASAN}

\section{Hasil Uji Reliabilitas.}

a. Skala Konsep Diri Akademik

Uji validitas Konsep Diri Akademik dilakukan dengan menggunakan analisis rasional dan profesional judment. Estimasi reliabilitas menggunakan program statistik SPSS 15.0 for window, dari 45 aitem yang disajikan terpilih 29 yang gugur yaitu nomor 2, 5, 6 9, 14, 19, 24,25, 29, 30, 31, 34, 35, 38, 43, 44. Koefisien korelasi antara skor aitem dengan skor total skala berkisar antara $r=0,313$ sampai $r=0,557$ sementara koefisien relibilitasnya adalah 0,891 .

Table I

Sebaran skala konsep diri Akademik

\begin{tabular}{|l|l|l|l|}
\hline \multirow{2}{*}{ Aspek } & Aitem & \multirow{2}{*}{ Total } \\
\cline { 2 - 3 } & Favorable & Unfavorable & \\
\hline Kepercayaan diri & $2,4,5,7,15,17,29$ & $1,11,19,26,27$ & 12 \\
\hline Penerimaan diri & $6,8,16$ & $10,12,20,22,24$ & 8 \\
\hline
\end{tabular}




\section{Irfani}

ISSN 1907-0969 E ISSN 2442-8272

Volume 14 Nomor 1 Juni 2019

Halaman 25-35

http://journal.iaingorontalo.ac.id/index.php/ir

\begin{tabular}{|l|l|l|l|}
\hline Penghargaan diri & $3,9,14,18,21$ & $13,23,25,28$ & 9 \\
\hline Total & 15 & 14 & 29 \\
\hline
\end{tabular}

b. Skala Belajar Berdasar Regulasi Diri

Uji validitas Belajar Berdasar Regulasi Diri dilakukan dengan menggunakan analisis rasional dan profesional judment. Estimasi reliabilitas menggunakan program statistik SPSS 15.0 for window, dari 80 aitem yang disajikan terpilih 66 aitem, aitem yang gugur yaitu nomor $3,4,5,11,19,25,28,32,40,47,66,73,78,79$. Koefisien korelasi antara skor aitem dengan skor total skala berkisar antara $r=0,307$ sampai $r=$ 0,577 , sementara koefisien relibilitasnya adalah 0,947 .

Table II

Sebaran Skala Belajar Berdasar Regulasi Diri

\begin{tabular}{|l|l|l|l|}
\hline Komponen & Dimensi & No. item & total \\
\hline Motivasi & Nilai Intristik & $6,13,52,55,61,65$ & 6 \\
& Nilain ekstrinsik & $1,39,42$ & 3 \\
& Nilai tugas & 14,23 & 2 \\
& Efikasi diri & $4,18,35,46,64$ & 5 \\
& Keyakinan control & $11,21,22,30,54$ & 5 \\
& Cemas menghadapi ujian & 43,62 & 2 \\
\hline Regulasi & Perencanaan Pemantauan & $16,29,31,41,48$ & 5 \\
metakognitif & Penilaian diri & $9,15,57$ & 3 \\
& & 33,53 & 2 \\
\hline Strategi koqnitif & Mengulang & $6,29,31,41,48$ & 5 \\
& Organisasi & $2,10,12,28,66$ & 5 \\
& Elaborasi & $3,32,34,37,45$ & 5 \\
\hline Strategi & Berfikir kritis & $17,26,47,51$ & 4 \\
\hline Pengelolaan & Kelola lingkungan & $5,19,27,36,50$ & 5 \\
Sumgkungan dan Daya & Regulasi Usaha & $24,40,45,58$ & 4 \\
\hline Jumlah & Mencari bantuan & $7,20,25,60,63$ & 5 \\
\hline
\end{tabular}




\section{Irfani}

ISSN 1907-0969 E ISSN 2442-8272

Volume 14 Nomor 1 Juni 2019

Halaman 25-35

http://journal.iaingorontalo.ac.id/index.php/ir

\section{Uji Asumsi}

Uji asumsi yang dilakukan dalam penelitian ini adalah uji normalitas sebaran data, uji linearitas .

\section{a. Uji Normalitas}

Tabel. 7

Hasil Uji Normalitas

\begin{tabular}{|l|l|l|l|}
\hline Variabel & K-SZ & P & Keterangan \\
\hline $\begin{array}{l}\text { Belajar Berdasar } \\
\text { Regulasi Diri }\end{array}$ & 0,402 & 0,997 & Normal \\
\hline $\begin{array}{l}\text { Konsep Diri } \\
\text { Akademik }\end{array}$ & 0,783 & 0,572 & Normal \\
\hline
\end{tabular}

\section{b. Uji Linieritas}

\section{Tabel 8}

\section{Hasil Uji Linieritas}

\begin{tabular}{|l|l|l|l|}
\hline Variabel & F & P & Keterangan \\
\hline Belajar Berdasar & 21,224 & 000 & Linier \\
Regulasi & & \\
Diri dengan Konsep & & & \\
Diri & & & \\
Akademik & & & \\
\hline
\end{tabular}

\section{Uji Hipotesis}

Hipotesis penelitian berbunyi ada hubungan antara konsep diri akademik dengan belajar berdasar regulasi diri pada siswa kelas XII MAN Kotamobagu. Hasil analisis regresi dari variabel menunjukkan $\mathrm{R}=0,407$ berdasarkan anova diperoleh nila $\mathrm{F}$ regresi $=$ 11,614 dengan $\mathrm{p}=0,00(\mathrm{p}<0.01)$ artinya konsep diri akademik berkorelasi sangat signifikan dengan belajar berdasar regulasi diri pada siswa kelas XII MAN Kotamob. Sumbangan efektif variabel bebas tercermin dalam harga keofisien $\mathrm{R}$ square sebasar 0,166 artinya $16,6 \%$. Hal ini berarti bahwa secara bersama sama variabel dari belajar berdasar regulasi diri bisa dijelaskan oleh variabel konsep diri sedangkan sisanya 83,4\% dijelaskan oleh variabel-variabel lain yang tidak dilibatkan dalam penelitian ini. Nilai yang diperoleh dari korelasi parsial sebesar $=0,402 \mathrm{t}$ hitung $=0,4737$ dengan $\mathrm{p}=0.00(\mathrm{p}$ $<0.01$ ). Dengan demikian Hipotesis penelitian yang diajukan diterima artinya terdapat hubungan positif yang sangat signifikan antara konsepdiri akademik dengan belajar berdasar regulasi diri pada siswa kelas XII MAN Kotamobagu. 


\section{Irfani}

ISSN 1907-0969 E ISSN 2442-8272

Volume 14 Nomor 1 Juni 2019

Halaman 25-35

http://journal.iaingorontalo.ac.id/index.php/ir

\section{HUBUNGAN KONSEP DIRI AKADEMIK DENGAN BELAJAR BERDASAR REGULASI DIRI}

Hipotesis penelitian yang diajukan adalah ada hubungan positif antara konsep diri akademik dengan belajar berdasar regulasi diri pada siswa kelas XII MAN Kotamobagu Sulawesi Utara. Artinya semakin tinggi konsep diri akademik belajar berdasar regulasi diri menjadi meningkat. Dalam menjalankan tugasnya sebagai pelajar untuk mencapai hasil yang optimal siswa perlu memiliki strategi dalam proses pembelajarannya. Strategi tersebut melibatkan unsur metakognisi, motivasional dan perilaku belajar (Zimmerman, 1989). Strategi dalam belajar tersebut disebut dengan belajar berdasar regulasi diri. Kemampuan siswa untuk melakukan belajar berdasar regulasi diri tidak secara otomatis akan muncul apabila salah satu faktor pendukunganya dalam hal ini faktor internal individu tidak terbentuk dengan baik, karena seperti yang diungkapkan oleh Zimmerman \& Schuck (dalam Boekaerts dkk., 2000) belajar berdasar regulasi diri adalah siswa membangkitkan pikiran, perasaan dan tindakan, yang merupakan suatu sistim orientasi yang mengarah pada pencapaian tujuan dalam hal ini menghasilkan performasi akademik yang baik.

Konsep diri akademik sebagai faktor internal atau dalam konsep kognitif sosial sebagai aspek individu/person yang menurut Santrock (2004) faktor individu tersebut meliputi faktor kepribadian dan kognitif yang meliputi intelegensi, keterampilan, emosi dan pengendalian diri, penilaian diri, persepsi diri, tujuan, keyakinan. Konsep diri akademik sebagai faktor individu/person terbentuk dari pandangan individu bersangkutan tentang kemampuan dalam pelajaran sekolah berdasarkan hasil perbandingan anatar kemampuan dirinya dengan temannya atau ada penilaian dari guru. Konsep diri akademik yaitu persepsi, evaluasi, penilaian siswa akan kemampuan akademiknya yang menyangkut aspek kepercayaan diri, penerimaan diri dan penghargaan diri. Dalam hal ini berarti siwa kelas XII MAN Kotamobagu memiliki persepsi atau penilaian tentang dirinya menyangkut kemampuan akademiknya. Setiap mata pelajaran yang ada di sekolah menjadi satu dimensi spesifik yang menyusun konsep diri akademik.

Kekuatan pada aspek personal dalam hal ini konsep diri akademik akan membantu mendorong individu dalam menetapkan tujuan ataupun goal yang akan dicapai, dalam hal ini keberhasilan atau penguasaan materi dalam belajar yang berarti mendorong individu untuk menunjukkan keterampilannya dalam belajar berdasar regulasi diri , seperti yang diungkapkan Zimmerman (dalam Boekaerts dkk, 2000) bahwa keterampilan meregulasi diri dalam belajar tidak ada artinya bila seseorang tidak mampu memotivasi dirinya untuk menggunakan keterampilan tersebut. Penetapan tujuan yang dilengkapi strategi yang tepat untuk mencapainya tidak akan terwujud tindakannya bila tidak disertai oleh komponen-komponen personal yang mampu memberikan dorongan dalam mengarahkan tindakan dalam mencapai tujuan. Sejalan dengan penelitian yang dilakukan oleh yang dilakukan oleh Dresel dan Haugwitz (2005) yaitu hubungan antara kemampuan kognitif dan belajar berdasar regulasi diri; interkasi dengan konsep diri akademik dan gender, hasilnya bahwa konsep diri akademik dalam pelajaran matematika 


\section{Irfani}

ISSN 1907-0969 E ISSN 2442-8272

Volume 14 Nomor 1 Juni 2019

Halaman 25-35

http://journal.iaingorontalo.ac.id/index.php/ir

memperantarai hubungan antara kemampuan kognitif dan penggunaan strategi dalam belajar.

Konsep diri akademik ini sebagai salah satu faktor pendukung dalam kelangsungan belajar siswa artinya siswa dengan konsep diri akademik yang positif akan mampu menjalankan aktivitas belajar dengan baik, karena memiliki penilain, persepsi, pandangan positif akan kemampuannya yang mendorong siswa belajar dengan optimal. Hal ini berarti pula siswa dalam belajar mampu belajar berdasar regulasi diri. Jadi siswa melakukan pengelolaan diri dalam belajar (self regulated learning) dengan pengertian suatu upaya yang mengacu pada kemampuan individu untuk mengatur dirinya dalam proses belajar, dengan mengikutsertakan kemampuan metakognisi, motivasi dan perilaku. Hal ini sesuai dengan yang dikemukakaan oleh Winne (dalam Santrock, 2004) siswa akan menjalankan proses belajar dengan lebih terarah maka siswa tersebut akan memperluas pengetahuannya, menjaga motivasi, menyadari keadaan emosi, dan punya strategi untuk mengelola emosinya, secara periodik memonitor kemajuan ke arah tujuannya, menyesuaikan atau memperbaiki strategi berdasarkan kemajuan yang mereka buat dan mengevaluasi halangan yang mungkin muncul dan melakukan adaptasi yang diperlukan dalam proses belajar, sehingga akan mencapai pembelajaran yang lebih efektif yang akan mewujudkan prestasi akademik yang lebih optimal. Atau sebaliknya apabila siswa dengan konsep diri akademik negative berarti ia memiliki persepsi, evaluasi atau penilain negatif tentang kemampuan akademiknya yang akan membuat siswa untuk tidak terdorong menjalankan aktivitas belajar dengan baik. Artinya ia pasif dalam aktivitas belajarnya artinya siswa tidak melibatkan proses motivasional, metakognitif dan perilaku atau strategi belajar untuk mencapai efektivitas belajarnya hal ini berarti siswa dalam belajar tidak memiliki kemampuan untuk melakukan belajar berdasar regulasi diri dalam mengolah materi pelajarannya.

\section{KESIMPULAN DAN SARAN}

\section{Kesimpulan}

Berdasarkan hasil penelitian maka peneliti menyimpulkan sbb :

1. Ada hubungan antara konsep diri akademik dengan belajar berdasar regulasi diri pada siswa kelas XII MAN Kotamboagu. Artinya bahwa konsep diri akademik dapat memprediksi belajar berdasar regulasi diri. Adanya interaksi yang simultan antara faktor personal, perilaku dan lingkungan akan menggerakkan siswa untuk melakukan belajar berdasar regulasi diri.

2. Ada hubungan positif yang sangat signifikan antara konsep diri akademik dengan belajar berdasar regulasi diri pada siswa kelas XII MAN Kotamobagu. Artinya semakin tinggi konsep diri akademik, semakin meningkat belajar berdasar regulasi diri, dan sebaliknya. Belajar berdasar regulasi diri akan muncul pada siswa yang memiliki konsep diri akademik positif sebagai aspek pesonal/individu. Konsep diri posistif artinya siswa memiliki penilain, evaluasi, pandangan positif akan kemampuan akademiknya, siswa menjadi merasa yakin akan kemampuannya, sehingga akan lebih mendorong siswa untuk mencapai tujuan. Siswa akan belajar dengan aktif, dengan menggerakkan komponen metakognisi, motivasional dan perilaku dalam belajar. Artinya siswa mampu untuk belajar berdasar regulasi diri. 


\section{Irfani}

ISSN 1907-0969 E ISSN 2442-8272

Volume 14 Nomor 1 Juni 2019

Halaman 25-35

http://journal.iaingorontalo.ac.id/index.php/ir

Konsep diri akademik merupakan dasar dari prestasi akademik dan perilaku akademik.

B. Saran.

Berdasarkan hasil penelitian tersebut maka penulis menyarankan sebagai berikut:

1. Memiliki penilaian diri yang positif akan kemampuan pada materi pelajaran akan membantu siswa untuk lebih mampu mengatur diri dalam proses pembelajaran. Untuk itu disarankan kepada siswa perlu menumbuhkan penilaian positif akan kemampuan dirinya dengan melakukan evaluasi atas apa yang telah dilakukan.

2. Untuk pihak sekolah dalam hal ini guru :

- Dalam proses belajar dapat digunakan pendekatan humanistik yaitu menganggap siswa individu yang aktif sehingga dalam proses pembelajaran lebih kepada student center learning.

- Memberikan kesempatan siswa untuk aktif dalam mengemukakan pendapat.

- Memberikan dorongan untuk memiliki penilaian positif akan kemampuannya dengan selalu memberikan reinforcement positif akan prestasi atau penguasaan materi pelajaran yang dicapai siswa.

- Memberikan feedback apabila siswa salah dalam melakukan tugas sekolah atau memahami pelajaran.

\section{DAFTAR PUSTAKA}

Ablard, K. E., \& Lipschultz, R. E. (1998). Self regulated learning in high achieving student relation to advanced reasoning achievement goals, and gender. Journal of Educational Psychology. 90, 94-101.

Alsa, A. (2005). Program belajar, jenis kelamin, belajar berdasar regulasi diri dan prestasi belajar matematika pada pelajar SMA Negeri di Yogyakarta. Disertasi. Tidak diterbitkan. UGM, Yogyakarta.

Boekaerts, M., Pintrich, R. P., Zeidner, M. (2000). Hanbook of self regulation. New York : Academic Press.

Byrne, M. B., \& Gayin, W. A. D. (1996). The Shavelson model revisited : Testing for the structure of academic self concept across pre- early and late adolescents. Journal of Educational Psychology. 88 (2), 215-228.

Chen, S. C. (2002). Self regulated learning strategies and achievement in an introduction to information system course. Journal Information Technology Leraning and Performance, 20 (1), 11-25.

Pintrich, R. P., \& De Groot,V. E. (1990). Motivational and self regulated learning component of classroom academic performance. Journal of Educational Psychology, 82 (1), 33-40.

Santrock, W. J (2004). Educational Psychology, (2nd ed.). Tri W.B.S (eds) : Psikologi Pendidikan : Jakarta Kencana.

Zimmerman, B. J. (1989). Asocial cognitive view of self regulated academic learning. Journal of Educational Psyschology, 81 (3), 329-339 